\title{
VEGETATIVE REPRODUCTION IN THE GENUS RICCIA (SUBGENUS RICCIA)
} ВЕГЕТАТИВНОЕ РАЗМНОЖЕНИЕ РОДА RICCIA (ПОДРОД RICCIA)

\author{
CHRISTIAN BERG $^{1}$, FERNANDO FERNANDEZ-MENDOZA ${ }^{1}$, RUTH BROOKS ${ }^{2}$, THOMAS STADLOBER ${ }^{1}$ \\ \& MARTINA PÖLTL ${ }^{3}$ \\ КРИСТИАН БЕРГ ${ }^{1}$, ФЕРНАНДО ФЕРНАНДЕС-МЕНДОЗА ${ }^{1}$, РУФЬ БРУКС ${ }^{2}$, ТОМАС СТАДЛОБЕР $^{1}$, \\ МАРТИНА ПЁЛТЛ ${ }^{3}$
}

\begin{abstract}
In cultivation experiments we studied growth behavior on living material of several Riccia-species as a part of the Austrian Riccia-Project. By documenting plant growth from natural habitats and from our living collection by photographs, we could show the known types of propagation (1) fragmentation of the rosettes and (2) apical tubers. In addition, we documented sprouting as a third important and somewhat forgotten type of vegetative reproduction within the subgenus Riccia. We conclude that various Riccia-species have a high potential for vegetative reproduction which allows species to keep or resettle habitats after harsh periods like drought or after changes of light conditions.
\end{abstract}

Резюме

В экспериментах по культивированию мы изучали рост нескольких видов Riccia в рамках австрийского проекта “Riccia”. Документируя рост растений из естественной среды обитания и из нашей живой коллекции с помощью фотографий, мы смогли показать известные типы размножения (1) фрагментация розеток и (2) верхушечные клубни. Кроме того, мы задокументировали прорастание как третий важный и несколько забытый тип вегетативного размножения в подроде Riccia. Мы пришли к выводу, что различные виды Riccia обладают высоким потенциалом вегетативного размножения, который позволяет видам сохранять или заселять места обитания после суровых периодов, таких как засуха, или после изменения условий освещения.

KEYWORDS: Riccia, Hepaticae, Marchantiales, vegetative growth, propagation, distribution, cultivation

\section{INTRODUCTION}

The delimitation of species within the genus Riccia $\mathrm{L}$. remains an unsolved issue in bryophyte taxonomy. Schuster (1992: 425) already identified "profound problems" in understanding species limits in Riccia and suggests several approaches and techniques to mitigate them, namely: "(1) Careful field study, over time, of masses of material. (2) Search for sites where two or even tree related taxa occur intermingled. (3) Cultivation experiments ...".

With the aim of clarifying the taxonomic delimitation within the genus Riccia, and to harmonize the different taxonomic concepts found among geographic regions (Pöltl et al., 2020), we assembled an extensive dataset in 2018. Following Schuster's proposal, we studied several hundred living specimens from the subgenus Riccia collected around Europe and established a living collection at the Botanical Garden of the University of Graz.

This living collection, meant to provide us with a deeper insight into the stability of morphological char- acters in the genus, also allow us to observe the growth, senescence and regeneration of Riccia thalli during the completion of their lifecycle.

The vegetative reproduction of Riccia species has been treated quite differently in modern monographies of the genus. Perold (1991), Schuster (1992), Paton (1999) and Damsholt (2002) noted that while all species multiply vegetatively through the fragmentation of their rosettes, some species are also able to regenerate from apical or ventral tubers. Meanwhile Jovet-Ast (1986) identified that vegetative reproduction in Riccia is also achieved by sprouting of any cell of the thallus, mainly on the thallus border or near thallus fractures. Such adventitious branches are also mentioned by Damsholt (2002) and Paton (1999) for Riccia fluitans.

In older Riccia literature we find several reports about sprouting as a type of vegetative reproduction. Already Leitgeb (1879), who cultivated many Riccia thalli in Graz 140 years ago, mentioned that all Riccia species are able

1 - Institute for Biology, University of Graz, Holteigasse 6, 8010 Graz, Austria, Email: christian.berg@uni-graz.at; OSCID (CB): 0000-0002-0587-3316; (FM): 0000-0002-0328-0808

2 - Sanibel Captiva Conservation Foundation, 3333 Sanibel-Captiva Road, 33957 Sanibel, Florida, USA. Email: wings.ruth@gmail.com.

3 -Studienzentrum Naturkunde, Universalmuseum Graz, Weinzöttlstraße 16, 8045 Graz, Austria. E-mail: martina.poeltl@museumjoanneum.at; ORCID (MP): 0000-0002-3001-058X 

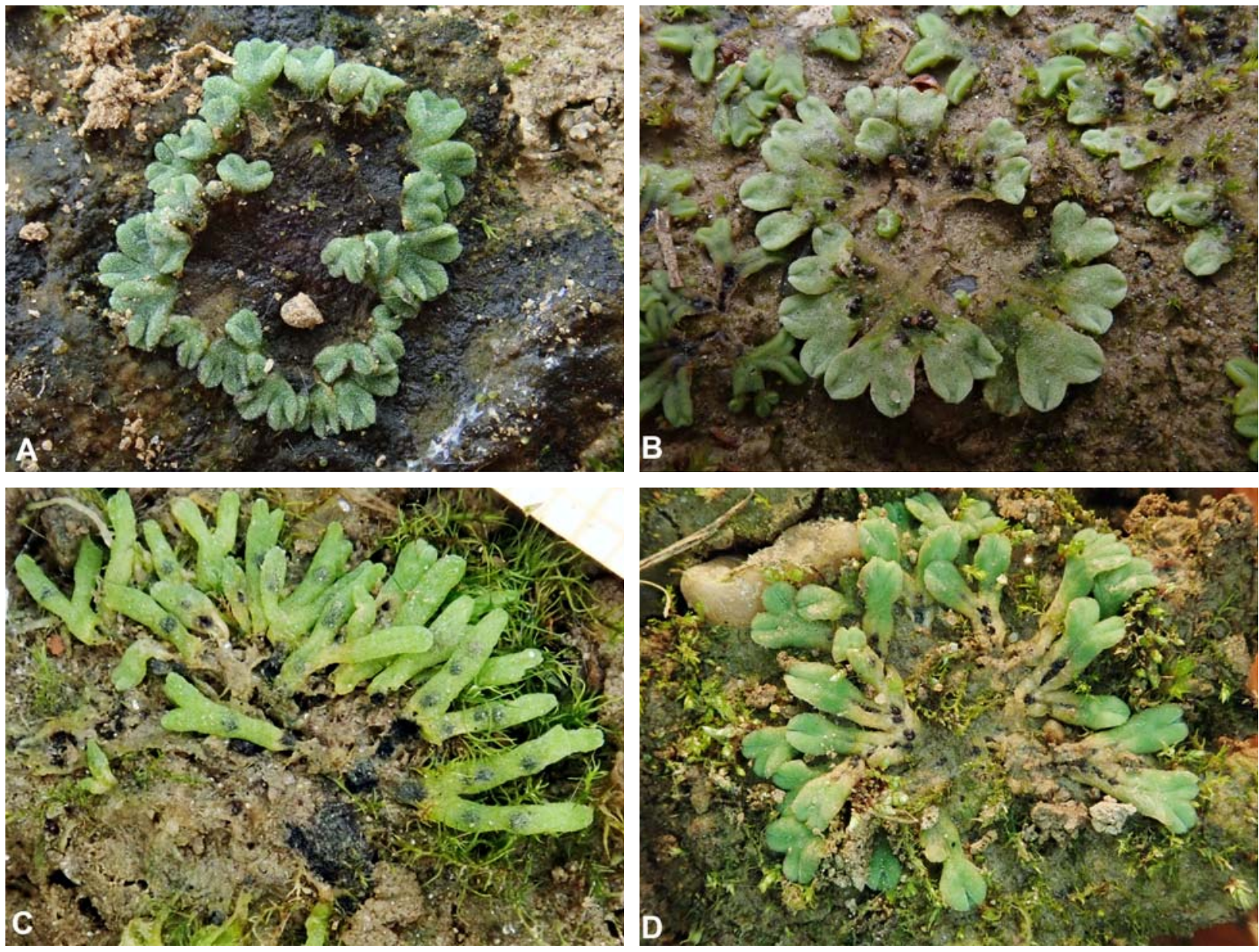

Fig. 1: Rosettes of Riccia species, which disintegrate into individual thalli through decay of the older thallus parts. A Riccia glauca, B Riccia bifurca, C Riccia warnstorfii, D Riccia sorocarpa (all material from Austria, Styria, leg. C. Berg \& M. Pöltl).

to propagate by means of adventitious sprouts, grown on the ventral side of the middle of the thallus. The author concludes, that "probably from all cells of a thallus a development of new plants is possible under favourable circumstances" (Leitgeb, 1879: 23). Sprouts are young thallus segments that can grow from any cell of a parent thallus and resemble it in structure. No protonema stage is interposed. Like brood bodies, shoots are used for vegetative reproduction. Schostakowitsch (1894) and Müller (1954) mentioned the same ventral adventitious sprouts for liverworts, and Müller (1954) added, that in cases of dying thalli these adventive sprouts also emerge on the dorsal side.

While bryophyte gametophyte grows from the differentiation of apical meristematic cells (Müller, 1954; Gifford, 1983; Hébant, 1978), bryophyte cells remain totipotent (Malcolm \& Malcolm, 2000), so protonema, stems, leaves, and rhizoids do contain a significant potential for vegetative sprouting (Frey \& Kürschner, 2011), which has been successfully used for in-vitro cell cultures (Duckett et al., 2004).

The ability of Riccia species to regenerate via sprouting from vegetative cells seems to be a somewhat forgot- ten and poorly documented trait, which has not been previously verified under natural conditions.

In this manuscript we document graphically the different mechanisms of vegetative reproduction in Riccia thalli, present evidence for the existence of sprouting in the subgenus Riccia and provide a discussion on the latter form of vegetative reproduction putting it in an ecological context.

\section{MATERIAL AND METHODS}

Within our European study of the subgenus Riccia the morphological part consists of analyzing fresh collected Riccia-plants in detail by gaining data by measurements (thalli characteristics including cross-sections, size and ornamentation of spores, etc.) as well as by extensive photographic documentation of the plants in nature, and in our established living collection. The cultivated samples come from different areas of Europe, collected and shipped by colleagues and supporters of the project. The number of samples and species fluctuates over the year depending of the material, so especially thalli of populations without sporophytes at the time of collection were cultivated to produce mature individuals. When we got much of material of one collection, we 

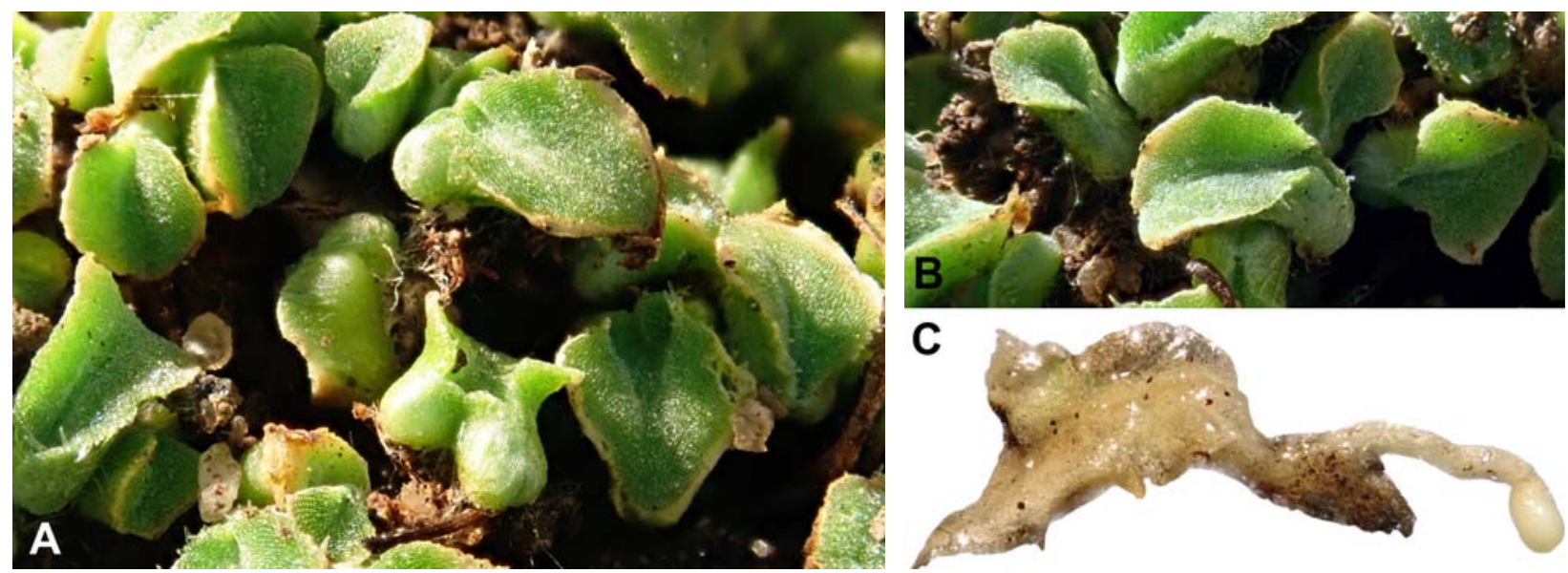

Fig. 2: Apical tubers in Riccia ciliifera agg. (R. gougetiana). A and B show the thickened thallus apices growing into the substrate (material from Spain, Salamanca, leg. Fernando Fernandez-Mendoza). C shows a thallus with an apically lowered thallus tip, from which in turn a branch with an egg-shaped tuber deeper into the substrate grows (material from US, Florida, Sanibel Island, leg. Ruth Brooks).

cultivate on part of the thalli to see how they grow and develop. Riccia thalli are cultivated in natural soil in small plastic boxes to maintain humidity in a Memmet climate chamber with 18.00 to 6.00 o'clock dark and $6^{\circ} \mathrm{C}, 6.00$ to 12.00 o'clock $85 \%$ light and $12^{\circ} \mathrm{C}, 12.00$ to 15.00 o'clock $95 \%$ light and $16^{\circ} \mathrm{C}$, and 15.00 to 18.00 o'clock $85 \%$ light and $12^{\circ} \mathrm{C}$. The light conditions were adapted to the length and intensity of an autumn day at our latitudes. To study the growth and morphological changes during cultivation, we primarily used material from Styrian lowlands growing on arable fields, as we can always collect material if we want to replicate attempts in case. The material under morphological investigation belongs to the four regionally most common species $R$. bifurca Hoffm., $R$. glauca L., $R$. sorocarpa Bisch. and $R$. warnstorfii Limpr. ex Warnst. We therefore made about 70 series of photo images of cultivated Riccia thalli with one picture each week. Cultures of more perennial species such as the $R$. ciliifera Link group, were checked in the course of the care of the cultivates, where the organs for persistence described below could be observed. We have so far cultivated 255 collections of approximately 21 species at least for a while. The work is still in progress. Pictures were made with an Olympus Tough TG-5 compact camera with macro focus stacking mode. Nomenclature of species mentioned here follows Hodgetts et al. (2020).

\section{RESULTS}

\section{Fragmentation of the rosettes}

Consistent with the idea of apical cells (Müller, 1954; Gifford, 1983; Hébant, 1978) driving the development of bryophyte thalli, the apical part of thallus segments behaves as vegetative poles in all studied Riccia specimens. The lack of vascular specialization in liverwort thalli results in a low functional interdependence between thallus segments. Because apical growth takes place independently of the fate of older thallus parts, when the apical fragment of a thallus lobe is excised, it can continue growing in culture with an unaltered morphology.

The senescence of inner thallus parts causes the fragmentation of rosettes often observed in natural populations, which ultimately leads to growing tips becoming independent from each other (Figs. 1A-D). Beyond vegetative multiplication, senescence of old thallus parts contributes to the dispersal of sexual propagules, as meiospores are released from decayed capsule walls (Fig. 1B).

\section{Apical tubers}

This type of vegetative propagation is less frequent in our culture collection. In Europe and North America, Riccia ciliifera s. 1. (mainly $R$. gougetiana Durieu \& Mont.) is known for the presence of apical tubers (Jovet-Ast, 1986; Schuster, 1992). The thallus apex is somewhat swollen, the marginal wings are reduced and the apex grows vertically in the ground. In some cases, a short or long stalked egg-shaped tuber is buried in the substrate by the plants (Fig. 2).

\section{Adventitious sprouts}

During the course of the culture collection we observed the development of adventitious sprouts in multiple Riccia species, especially in short-living species growing in arable fields: $R$. glauca, Riccia bifurca, $R$. warnstorfii and (rare) in $R$. sorocarpa. Such specimens seem to reach a physiological limit (Fig. 3:4) after which they stop growing and decay (Fig. 3:4-10), only to resprout from lobe apices (Fig. 3: 12-19).

In the example of figure 3 , the thallus stopped its growth in the transition between field and culture conditions. After it was transferred to a climate chamber, it stopped growing immediately and commenced to decay. After 8 weeks, the plant seemed to have died, but two weeks later new segments began to sprout from the dorsal side of older lobes. After 19 weeks, the new thalli take up about the same area as the old rosette. 

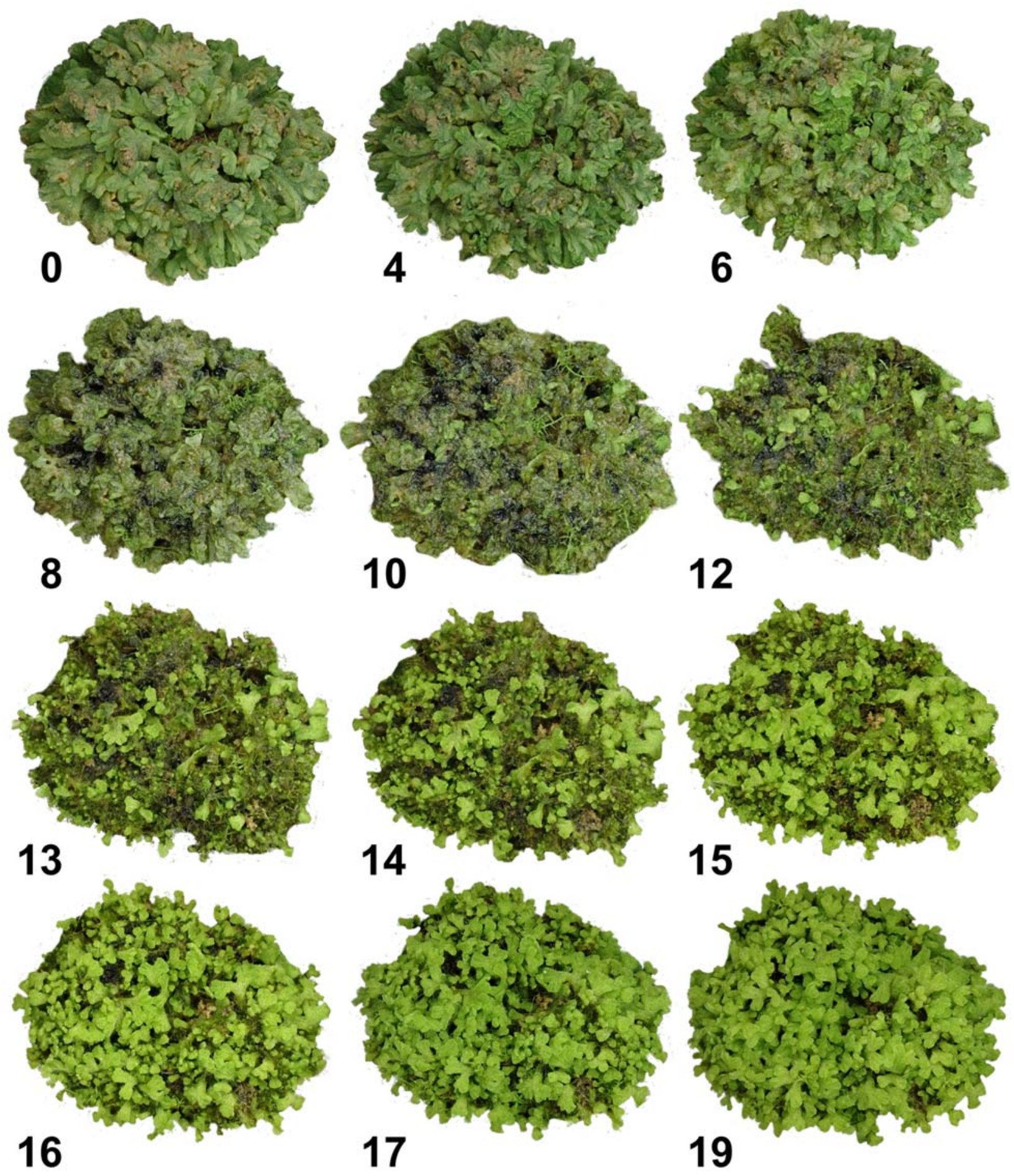

Fig. 3: A sequence of pictures of a dense rosette of Riccia glauca, collected in Austria, Styria, Feldbach, Berndorf SE Kirchberg an der Raab, N 46.969 E15.793, 300 m s. m., pumpkin field, 16.XI.2019, leg. M. Pöltl. The numbers indicate the timeline (weeks after collection). After a time of decay (week 1-8) young, light green sprouts appear on the dorsal side of the rotten thallus (week 10-19).

After we documented the phenomenon under culture conditions, we were also able to observe it in the field, and identified some particular growth anomalies in Riccia rosettes that are better explained by resprouting (Fig. 4). In the senescent central part of rosettes, we also found smaller, younger thallus segments filling the center of the rosettes. Figure 4A depicts a lobe of Ric- cia bifurca that was excavated by a feeding insect or worm to the point where only the contour of the thallus was preserved. However, numerous small sprouts had already formed on the dorsal surface, proving that functioning sprouts do not need to be connected to the abaxial parenchyma, but can also originate from isolated assimilative cells. 

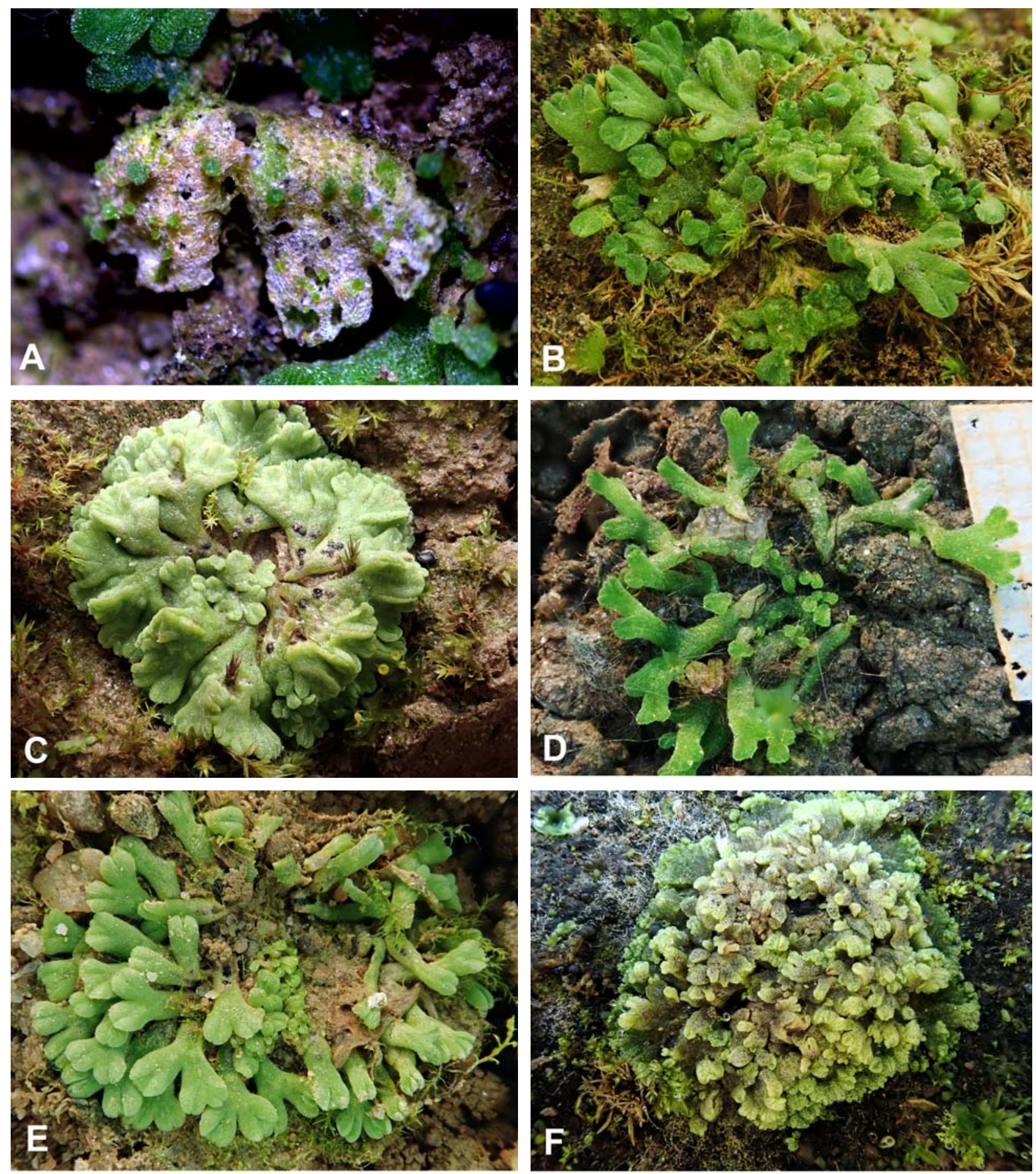

Figure 4: Different pictures of Riccia rosettes from natural habitats with young sprouts in the center. A Riccia bifurca $\mathbf{B}$ Riccia bifurca $\mathbf{C}$ Riccia glauca $\mathbf{D}$ Riccia warnstorfii $\mathbf{E}$ Riccia sorocarpa $\mathbf{F}$ Riccia cavernosa

\section{DISCUSSION}

Besides discoid gemmae known from $14 \%$ of the species of the Marchantiales (like Marchantia or Lunularia, Bischler, 1998), asexual reproduction is rare in the order Marchantiales, and sprouting is unknown apart from the observations reported here on the genus Riccia. Through investigations in our Riccia living collection and observations in nature, we were able to prove that Riccia thalli, also of the subgenus Riccia, have the ability to regenerate via sprouting, without any intermediate protonema development. This was little known until now and was mainly attributed to the subgenus Ricciella (A. Braun) Boulay, and in particular to the best studied and mainly sterile species, Riccia fluitans (Damshold, 2002; Paton, 1999).

When Riccia thalli were transferred to culture conditions, sprouting occurred especially when the individuals 
could not cope with the culture conditions and grew poorly or not at all. In the experience of Müller (1916), this was probably due to the sudden change in light conditions. There seems to be an adaptation process of the photosynthetic performance, which allows the thalli to continue growing after a few weeks of lag phase with the help of sprouting. It would certainly be interesting to investigate this adaptation phenomenon to changed light conditions in more detail.

In the field, we could observe sprouting in several species as well. Without the knowledge of the sprouting capacity of decayed older thallus parts, the young thalli in the middle of a rosette, like in figure $4 \mathrm{C}$ and $\mathrm{E}$, could also be interpreted as a result of germinated spores. However, in longitudinal section the connection of the sprouts with the old thallus is visible. According to our observations, spores are very quickly removed by rain and hardly ever remain in clumps after release.

Contrary to Leitgeb (1879) and others who also found ventral sprouts in Riccia, we only observed dorsal ones. This sprouts in Riccia are often numerous, but are not caducous like in Metzgeria. Their connection with the deterioration of environmental conditions shows that they serve more for survival than for reproduction. Müller (1954) and Newton \& Mishler (1994) emphasized that vegetative reproduction increased under more stressful conditions. It is known that spore production and the production of vegetative propagules often exclude each other (Glime, 2017), and we normally find sprouts on thalli without capsules and not during spore development (Berg \& Pöltl, 2020). Sprouting in Riccia as a reaction to a sudden change in light conditions makes sense for the survival of the species. In arable fields in Central Europe, the species grow parallel to the crop, mostly cereals or maize, during wet summers or towards autumn. Due to the dense crop they have to adapt to relatively shady conditions. On the harvest day, in late summer for winter crops or in autumn for summer crops, light suddenly changes to much brighter conditions. Now, the bestknown habitat of the short-lived Riccia species in Central Europe emerges: the stubble field. Therefore, similar growth inhibitions can occur as in the climate chamber, when light conditions change in a moment, and sprouting can be a means to adapt. Species in the Mediterranean region or on dry grasslands could be affected in a similar way. The growth period here is in mild winters and wet spring, while the plants then fall into a poikilohydric dry phase in the hot dry summer. After re-wetting in autumn, the light conditions are clearly different, so that a renewal of the thalli by sprouting would also enable an adaptation to the new conditions. Cavers (1903) reported that several species of Riccia which inhabit dry regions produce special ventral branches, and Perold (1991: 80) stated that "The ability to maintain populations by asexual propagation may have been crucial in allowing survival under marginal climatic conditions, during periods of climatic stress".
In this context it is striking that species that occur both in fields and in dry grasslands (e.g. Riccia sorocar$p a, R$. bifurca) often do not grow in rosettes in the latter habitat, but in tangled interwoven mats. It can be concluded from Figure 3:19 that this growth form could also result from sprouting. Often the growth in rosettes or in interwoven mats is listed as a species characteristic. Like many other morphological features of the genus, the expression of the growth habit seems to have an environmental component.

In contrast, reproduction by decay of thalli is of little reproductive significance. It results in several individuals from one former rosette. However, since the thallus tips of Riccia are in any case independent growth units and independent of the older thallus parts, the question of whether the thallus is still whole or decayed is not important. The decay serves to release the spores, and the emergence of separate individuals from the growing thallus tips is more likely a side effect of this process. It is difficult to imagine that these individuals could somehow serve to spread the species. But the permanent growth on the thallus apex gives the short living species the ability to be potentially perennial, as we could observe in our climate chamber and as Gaisberg (1921) already stated one hundred years ago.

This applies to a greater extent for the apical tubes, for example in the Riccia ciliifera group. Since only one tuber develops from each thallus tip, these are not a form of reproduction at all, but a measure of survival in case of dry periods (Schuster, 1966). In arid climate such as in South Africa, this is a widespread strategy of several Riccia-species (Cavers, 1903; Volk, 1984; Perold, 1991). The thallus dies at the start of the dry season, leaving only the thallus tip, the place of the active growth, alive. These tips are more swollen, globose and are brought deeper in the substrate. This reduces the surface of the tuber, and opens space for the storage of water and nutrients (Volk, 1984) - typical reactions for surviving dry conditions. Schuster (1966) reported from similar tuberous swellings of the thallus apex in Petalophyllum and in some Fossombronia species.

The stalked tubers are smaller, for this they are buried even deeper as an evaporation protection. Schuster (1992) presented drawings of the tuberous thallus tips of Riccia gougetiana, and Jovet-Ast (1970) showed drawings of stalked, egg-shaped tubers of Riccia perennis Steph. (Subgenus Ricciella), presented as photographs by Hugonnot \& Chavoutier (2021).

The connection between dying thalli and sprouting has led us to consider whether the many living thalli of species in the fields that are ploughed under every autumn could possibly sprout again the next year. In a field densely covered with thousands of young thalli, we examined many hundreds of them and could in no case prove a connection with older thallus pieces. So, we consider that sprouting can ensure the survival of plants in 
order to adapt to changing light conditions, but the most important type of reproduction in the subgenus Riccia is reproduction via spores.

\section{LITERATURE CITED}

BERG, C. \& M. PÖLT. 2020. Spore development during capsule maturation of three Riccia species. - Herzogia 33: 179-187. https://doi.org/ 10.13158/heia.33.1.2020.179

BISCHLER, H. 1998. Systematics and evolution of the of the genera of the Marchantiales. - Bryophytorum Bibliotheca 51: 1-153.

CAVERS, F. 1903. On asexual reproduction and regeneration in Hepaticae. - New Phytologist 2: 121-133.

DUCKETT, J.G., J. BURCH, P.W. FLETCHER, H.W. MATCHAM, D.J. READ, A.J. RUSSELL, \& S. PRESSEL. 2004. In vitro cultivation of bryophytes: a review of practicalities, problems, progress and promise. - Journal of Bryology 26: 3-20.

DAMSHOLT, K. 2002. Illustrated Flora of Nordic Liverworts and Hornworts (2nd ed.). - Nordic Bryol. Soc., Lund, 842 pp.

GAISBERG, E. VON. 1921. Beiträge zur Kenntnis der Lebermoosgattung Riccia. - Flora 114: 262-277.

GLIME, J. M. 2017. Adaptive Strategies: Vegetative vs Sexual Diaspores. Chapt. 4-7. - In: Glime, J. M. Bryophyte Ecology. Volume 1. 4-7-1 Physiological Ecology. Ebook sponsored by Michigan Technological University and the International Association of Bryologists. Last updated 17 July 2020 and available at <http://digitalcommons. mtu.edu/bryophyte-ecology/>

FREY, W., \& H. KÜRSCHNER. 2011. Asexual reproduction, habitat colonization and habitat maintenance in bryophytes. - Flora 206: 173 184. https://doi.org/10.1016/j.flora.2010.04.020

GIFFORD, E. M. Jr. 1983. Concept of apical cells in Bryophytes and Pteridophytes. - Annual Review of Plant Physiology 34: 419-440.

HÉBANT, C., R. HÉBANT-MAURI \& J. BARTHONNET. 1978. Evidence for division and polarity in apical cells of bryophytes and pteridophytes.-Planta 138: 49-52

HODGETTS, N. G., L. SÖDERSTRÖM, T. L. BLOCKEEL, S. CASPARI, M. S. IGNATOV, N. A. KONSTANTINOVA, N. LOCKHART, B. PAPP, C. SCHRÖCK, M. SIM-SIM, D. BELL, N. E. BELL, H. H. BLOM, M. A. BRUGGEMAN-NANNENGA, M. BRUGUÉS, J. ENROTH, K. I. FLATBERG, R. GARILLETI, L. HEDENÄS, D. T. HOLYOAK, V. HUGONNOT, I. U. KARIYAWASAM, H. KÖCKINGER, J. KUCERA, F. LARA \& R. D. PORLEY. 2020. An annotated checklist of bryophytes of Europe, Macaronesia and Cyprus. Journal of Bryology 42(1): 1-116. https://doi.org/10.1080/ 03736687.2019 .1694329
HUGONNOT, V. \& J.L. CHAVOUTIER. 2021. Les Bryophytes de France Volume 1: Anthocérotes et Hépatiques. - Biotope Éditions, Mčze, 661 pp.

JOVER-AST, S. 1970. Riccia perennis Stephani: Nomenclature, morphologie, caryotype, affinités. - Révue bryologique et lichénologique 37: $237-245$

JOVET-AST, S. 1986. Les Riccia de la région méditerranéenne. - Cryptogamie. Bryologie, Lichénologie, suppl. 7: 283-431.

LEITGEB, H. 1879: Untersuchungen über die Lebermoose. IV. Heft. Die Riccieen. - Verlag Leuschner \& Lubenski, Graz, $158 \mathrm{~S}$

MALCOLM, B. \& N. MALCOLM. 2000. Mosses and other bryophytes an illustrated glossary. - Micro-Optics Press, Nelson, New Zealand, $220 \mathrm{pp}$.

NEWTON, A.E. \& B.D. MISHLER. 1994. The evolutionary significance of asexual reproduction in mosses. - Journal of the Hattori Botanical Laboratory 76: 127-145. https://doi.org/10.18968/jhbl.76.0_127

MÜLLER, K. 1916. Über Anpassungen der Lebermoose an extremen Lichtgenuß. - Berichte der Deutschen Botanischen Gesellschaft 34: $142-152$.

MÜLLER, K. 1954. Die Lebermoose Europas. - In: Dr. Rabenhorst's Kryptogamen-Flora Deutschlands, Österreichs und der Schweiz, Band 6, 1. Abteilung. Akademische Verlagsgesellschaft Geest und Portig, Johnson Reprint Corporation, London, 756 pp.

PATON, J. A. 1999. The liverwort flora of the British Isles. - Harley Books, Colchester, 1-626.

PEROLD, S.M. 1991. A taxonomic revision of the Ricciaceae Reichenb. (Marchantiales: Hepaticae) in Southern Africa. - PhD-Thesis on the University of Pretoria, $228 \mathrm{pp}$.

PÖLTL, M., F. FERNANDEZ-MENDOZA \& C. BERG. 2020. The Austrian Riccia Morphology and Sequencing Project. - Bryological Times 151: $3-4$.

SCHOSTAKOWITSCH, W. 1894. Ueber die Reproductions- und Regenerationserscheinungen bei den Lebermoosen. - Flora 79: 350-384.

SCHUSTER, R.M. 1966. The Hepaticae and Anthocerotae of North America East of the hundredth Meridian. Vol. 1. - Columbia University Press, New York. 1-802.

SCHUSTER, R.M. 1992. Riccia [Micheli] L. - In: R.M. Schuster (ed.): The Hepaticae and Anthocerotae of North America East of the hundredth Meridian. Vol. 6. Field Museum of Natural History Chicago. p. 421-709.

VOLK, O.H. 1984. Beiträge zur Kenntnis der Marchantiales in Südwest-Afrika/Namibia. IV. Zur Biologie einiger Hepaticae mit besonderer Berücksichtigung der Gattung Riccia. - Nova Hedwigia 39: $117-144$ 